\title{
GANGLIONEURINOM RETROPERITONEAL CATECOLAMIN SECRETOR LA UN COPIL DE ŞASE ANI
}

\author{
Bauer Adalbert ${ }^{1}$ \\ ${ }^{1}$ medic primar pediatru, doctor în medicină
}

Title: Retroperitoneal ganglioneurinoma with catecholamine secretion at a six year-old child

Abstract: I present the case of retroperitoneal abdominal tumour of tissular neurologic originsganglioneurinoma, with benign evolution, at a six year old child, with a confusing succession of symptoms, in a cronic abdominal ache syndrome, where only the prolonged evolution provided conclusive arguments for positive diagnostic, respectively when the growth become palpable in the left part of iliac area. The start symptoms were the nonstructured abdominal ache, without anatomical topographic localization criteria. The cronic infection of urinary tract was caused by the left kidney stone produced through urinary stasis, in response to exterior compression by the growth on left ureter.

Key words: ganglioneurinoma, abdominal tumours, chatecolamine, infection of urinary tract.

Rezumat: Prezint un caz de tumoră abdominală retroperitoneală de origine tisulară nervoasăganglioneurinom, cu evoluție benignă, la un copil de șase ani, cu o cronologie derutantă a simptomelor în contextul unui sindrom dureros abdominal cronic, numai evoluția prelungită furnizând elemente convingătoare pentru precizarea diagnosticului pozitiv, respectiv când tumora a devenit palpabilă în fosa iliacă stângă. Simptomele de debut au fost durerile abdominale nesistematizate, fără criterii de localizare anatomotopografică. Infecția urinară cronică a fost pe fondul unei litiaze bezinetale stângi produsă prin stază urinară, urmare a compresiunii extraluminale a ureterului stâng de către formațiunea tumorală.

Cuvinte cheie: ganglioneurinom, tumori abdominale, catecolamine, infecție urinară.

\section{Prezentarea cazului.}

Copilul B.T. în vârstă de șase ani din Satu-Mare, în observația medicului de familie pentru dureri abdominale recidivante, intermitente, de tip colicativ, fără localizare specifică, a urmat tratamente repetate și ineficiente cu vermicide, pe parcursul evoluției de nouă luni simptomatologia persistând fără elemente de agravare sau de acutizare. În ultimele două luni tabloul clinic se completează cu o infecție urinară și o diaree trenantă, neinfluențabilă prin tratamente cu dezinfectante intestinale şi regimuri dietetice.

$\mathrm{Cu}$ ocazia ultimului control, medicul de familie pune în evidență o formațiune tumorală de mărime 3x3 cm în flancul stâng, de consistență fermă și fixată în regiunea suprapubiană. Copilul a fost îndrumat imediat la serviciul nostru, cu diagnosticul de tumoră abdominală de etiologie neprecizată.

La inspecție abdomenul este normal conformat, fără asimetrie între cele două flancuri, la palpare se evidenţiează o formațiune tumorală de consistență fermă, de mărimea unui ou de găină, nedureroasă, cu suprafață netedă, aderentă puternic planurilor profunde, cu localizare în flancul stâng, preponderent în fosa iliacă stîngă, fără contact lombar; pe marginea medială a tumorii se simt pulsații ample. Caracteristicile anatomo-clinice ale formațiunii tumorale ne orientează spre localizarea topografică retroperitoneală.

T,inând cont că în orice tumoră abdominală la copil este obligatorie urografia intravenoasă, am efectuat următoarele examinări radiologice: 
Radiografia abdominală simplă, care evidențiează o imagine opacă, de mărimea unui bob de porumb, în proiecția bazinetului stâng.

Urografia arată o hipotonie globală a căilor urinare reno-ureterale superioare, cu ectazii caliceale, bazinete şi uretere dilatate. La nivelul apofizei transverse L4, ureterul stâng hipoton şi dilatat face o cudură înainte şi înafară, cu întreruperea temporară a fluxului urinar; în continuare fluxul urinar este normal, stopul fiind realizat probabil prin compresiunea extraluminală a ureterului. Din proiecție antero-posterioară se evidențiează o umbră compactă, care proemină spre cavitatea abdominală din planurile profunde (retroperitoneal), bine delimitată în ansamblu şi de mărimea $3 \times 2 \mathrm{~cm}$. Din poziția oblică stângă apofizele transverse L4-şi L5 sunt uşor îndepărtate între ele, iar conturul anterior al corpului vertebral L5 este concav (atrofie prin compresiune) fără dispariția corticalei sau semne vizibile de invazie osoasă.

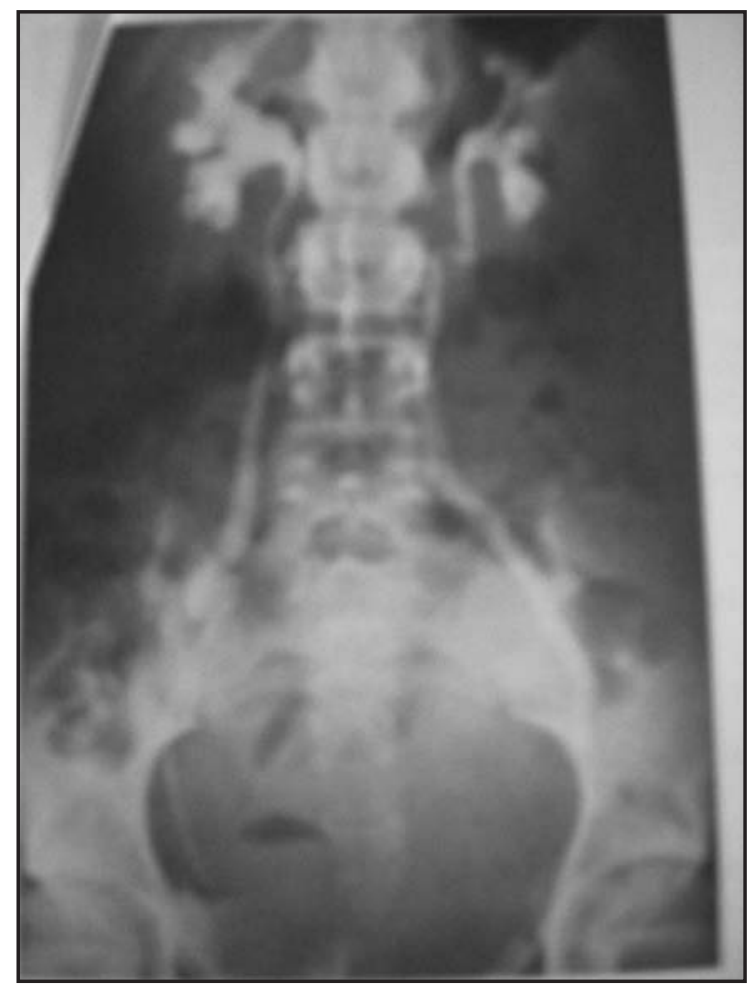

Reproducere după Caffey, J

Irigoscopie și irigografie: joncțiunea descendentă sigmoidiană a colonului este deplasată ușor înafară, fără modificări de contur şi de relief.

Radiografia pulmonară nu evidențiază modificări patologice.

Examinări de laborator: hematologice fără modificări patologice, VSH-normal, TA 90/65 mmHg. Examenul urinii: albumine urme. Reacția Esbach 0,15 mg \%, catecolamine urinare intens pozitive. Sedimentul urinar: 10-15 hematii și 20-30 leucocite, frecvente cristale de oxalați de calciu, floră microbiană bogată. Urocultură: bacili E.coli 1.000.000, sensibili la aminoglicozide (gentamicină, kanamicină).

Evoluția a fost afebrilă în tot timpul observației.

Infecția urinară a fost temporar cupată prin monoterapie cu gentamicină în doze și durată adecvate.

Caracterele clinice și radiologice decelate, au permis localizarea anatomo-topografică a tumorii în spațiul retroperitoneal. Excluzând existența unei tumori renale prin efectuarea urografiei, precum și a uneia pancreatice prin localizarea pelviană a tumorii, ne-am orientat în ordinea frecvenței tumorilor retroperitoneale la copii spre originea tisulară nervoasă extramedulară a neoformatului abdominal, sprijinindu-ne și pe modificările osoase ale corpului vertebral și a apofizelor la nivelul L4 și L5. 
Starea generală nealterată, persistența în limite normale a constantelor biologice, absența metastazelor, evoluția posibil prelungită argumentată de formarea unui calcul bazinetal prin mecanism de stază urinară, absența sindromului infecțios, au fost câteva elemente care au prezis natura benignă a neoformatului abdominal.

Intervenția chirurgicală și examenul histopatologic au confirmat diagnosticul nostru prezumptiv, stabilind ca entitate anatomo-clinică un ganglioneurinom retroperitoneal. Evoluția postoperatorie a fost favorabilă. La controalele ulterioare copilul este asimptomatic, cu rezerva urmăririi calculozei și a infecției urinare.

Ca o particularitate a cazului nostru menționăm sindromul diareic trenant și recidivant. Este cunoscut că în cadrul tablourilor clinice realizate de tumorile adreno-medulare, precum și cele provenite din țesutul nervos simpatic (feocromocitom, neuroblastom, ganglioneurinom), există o creștere excesivă a catecolaminei, substanța produsă de celule cromafine ale țesutului nervos simpatic. Mecanismul fiziopatologic al diareei cronice de către catecolamine nu este elucidat, dar se presupune o perturbare în metabolismul apei la nivelul segmentului digestiv.

Rosenstein a publicat cazuri de ganglioneurinoame catecolamin secretoare la copii, evidențiate preoperator prin determinarea excreției de catecolamină din urină. Se pare că și cazul nostru se încadrează în această entitate, întrucât după extirparea tumorii a cedat și diareea.

\section{Discuții}

Dacă în seria de tratate clasice de pediatrie (Glanzmann, Rominger, Feer) întâlneam referiri sumare la patologia tumorală, în tratatele moderne (Nathan, Shirkey, Kempe) patologia de neoformație este abordată în capitole distincte, cu încadrări nosologice bine precizate, cu perspective de abordare paraclinică, tratamente medicamentoase antineoplazice, asistență onco-chirurgicală.

Tumorile retroperitoneale la copii, cu toate că în marea majoritate sunt tumori renale, clinica și paraclinica neoformatelor de altă natură sunt prezente în lucrările pediatrilor, radiologilor, chirurgilor, oncopediatrilor: monografia Carpenter privind patologia neuroblastomului și ganglioneurinomului retroperitoneal, Hansman care descrie testele radiologice directe ale neuroblastomului retroperitoneal, studiul lui Gwinn despre teratoamele presacrale, iar a lui Hickey despre aspectele clinico-chirurgicale ale teratoamelor sacrococcigiene, Frantz publică cazuri de adenocarcinom și limfosarcom al pancreasului la copii, Ganein despre tumorile benigne al vezicii urinare, Mostofi despre rabdomiosarcomul vezical, Ficht despre carcinoame, iar Scott despre feocromocitomul vezicii urinare, Snyder descrie tumori de origine tisulară renală, pancreatică, nervoasă, lipoame, liposarcoame, fibrosarcoame, mezenchimoame beningne și maligne, limfangioame și hemangioame cu localizare în spațiul retroperitoneal. Evocăm aceste date din literatura pediatrică pentru demonstrarea polimorfismului etiologic al tumorilor retroperitoneale.

Diagnosticarea precoce și corectă a tumorilor retroperitoneale la copii este o piatră de încercare pentru clinician, oferind mai multe șanse terapeutice. Dificultățile diagnosticului în faza de debut sunt mai mari decât la adult, de cele mai multe ori fiind necesare examinări paraclinice laborioase, iar uneori impunându-se laparatomia exploratorie și biopsia. Problema benignității sau malignității unor tumori retroperitoneale este deseori mai ușor de lămurit decât cea a punctului de plecare. Malignitatea de obicei se traduce prin creșterea rapidă a tumorii, multiplicitatea ei, prezența metastazelor, afectarea stării generale, alterarea precoce a probelor biologice, apariția precoce a complicațiilor din partea organelor vecine, etc.

\section{Concluzii}

Am prezentat un caz de ganglioneurinom retroperitoneal, cu complicații urorenale neobișnuite: formare de calcul bazinetal prin stază urinară persistentă, consecința compresiunii extraluminale a ureterului.

Prezența diareei cronice și amendarea ei după extirparea chirurgicală a tumorii, a impus cazul ca un ganglioneurinom catecolamin-secretor. 
Particularitățile clinice a cazului prezentat subliniează importanța depistării precoce a neoformatelor retroperitoneale și soluționarea chirurgicală a lor, în vederea eliminării apariției complicațiilor.

\section{Referinţe}

1. Rosenstein, B,J, Engelman, K. Diarheea in a child with a catecholamine-secreting ganglioneurinoma. Case report and review of literature. J Pediat 1963;63:217.

2. Swift, PGF. Watery diarrhea and ganglioneurinoma with secretion of vasoactive intestinal peptide. Arch Dis Child 1975;5:876.

3. Melicow, MM. Palpable abdominal masses in Infants and Children. J Urol 1959;81:705.

4. Snyder, WH. Retroperitoneal Tumors in Infants and Children. Arch Sur 1951;63:26.

5. Nelson, EW. Texbook of Pediatrics 1964,1525

6. Shirkey, H. Pediatric Therapy. Mosby Company Saint-Luis 1975,1033-1035

7. Popescu, V. Tratat de Pediatrie, Editură Medicală, vol III

8. Fanconi, G, Wallgren, A. Manual de pediatrie, 340-342 